\title{
THE INDUSTRIAL ENGINEERING IDENTITY: FROM HISTORIC SKILLS TO MODERN VALUES, DUTIES, AND ROLES
}

\author{
H. Darwish ${ }^{1 \#^{*}} \&$ L. van Dyk
}

\section{ARTICLE INFO}

\section{Article details}

Presented at the $27^{\text {th }}$ annual

conference of the Southern African Institute for Industrial Engineering

(SAIIE), held from 27-29 October 2016

at Stonehenge in Africa, North West,

South Africa

Available online

11 Nov 2016

\section{Contact details}

Corresponding author

Hasan.Darwish@nwu.ac.za

\section{Author affiliations}

1 Department of Industrial Engineering, North-West University, South Africa

\# The author was enrolled for an $\mathrm{PhD}$ (Development \& Management) degree in the Department of Industrial Engineering, North-West University.

DOI

http://dx.doi.org/10.7166/27-3-1638

\section{ABSTRACT}

Over the past 100 years, engineering has sub-divided into tens of disciplines in an attempt to deal with the different problems arising from the wide spectrum of human endeavours. One particular field, however, arose from problems relating to industry, interdisciplinary integration, growth, balance, and connectedness. This field is known as industrial engineering (IE). Yet the IE identity and role, although useful, often remains vague. This article presents a review of the factors that made IE what it is today, as well as the fields differentiating the skills. It begins with a brief historical overview of the factors that shaped IE. More importantly, though, the article focuses on the modern identity (made up of the values, roles, and duties) of industrial engineers in the 21st century. This is done by showing that the long-standing cliché of industrial engineers being 'jacks of all trades and masters of none' has actually become 'connected to all trades and masters of some' due to a significant evolution of skills and identity. An industrial engineering identity (IE-ID) tree model is developed by extracting concepts and elements from existing identity models to give structure to the IE-ID model. The model is then populated with questions and answers arising from the literature review. To conclude, the future utility of such a model is anticipated.

\section{OPSOMMING}

Oor die afgelope 100 jaar, is ingenieurswese verdeel in tientalle dissiplines, in 'n poging om verskillende probleme te hanteer wat voorspruit uit 'n wye reeks menslike ondernemings. Een van hierdie velde het voortgespruit uit probleme wat verband hou met bedrywe, interdissiplinêre integrasie, groei, balans, en gekoppeldheid. Hierdie veld staan bekend as bedryfsingenieurswese (BI). Tog is die bedryfsingenieursidentiteit en -rol steeds nie duidelik nie. Hierdie artikel sluit 'n deeglike ondersoek in na dit wat $\mathrm{BI}$ maak wat dit vandag is (asook hulle onderskeidende vaardighede). Dit begin met ' $n$ kort historiese oorsig van die faktore wat BI gevorm het. Meer belangrik nog, fokus hierdie artikel op die moderne identiteit (bestaande uit waardes, rolle, en plig) van bedryfsingenieurs in die 21ste eeu. Dit word gedoen deur te wys dat die cliché dat bedryfsingenieurs 'alles doen, maar niks bemeester nie' uiteindelik, deur ' $\mathrm{n}$ proses van beduidende evolusie van vaardighede en identiteit, sodanig verander het dat hulle nou 'gekoppel is aan alles en heelwat bemeester'. ' $n$ Bedryfsingenieurs identiteit (IE-ID) boom-model is ontwikkel deur konsepte en elemente van bestaande identiteitsmodelle te gebruik om struktuur te verleen aan die IE-ID model. Die model is toe ingekleur aan die hand van vrae en antwoorde wat uit die literatuuroorsig gespruit het. Om af te sluit, word die toekomstige nut van hierdie model geantisipeer. 


\subsection{Introduction}

In the words of Nadeem Aslam, "Pull a thread here and you'll find it's attached to the rest of the world" [1]. When one looks at the development of industry over the centuries, one of the main conclusions to be reached is that industrial development surges when the barriers between separate technologies, knowledge fields, or specialisations are converted into connections [2]. Sometimes, the 'thread' that matures these connections can be an overlooked idea, equation, technology, philosophy, or shared method. This is often due to certain ideas or philosophies, belonging to a specific knowledge area, being applied more broadly or being merged in a way that answers a problem in another field. More often than not, identifying these connections can cause the development of entirely new industry sectors, sub-specialities, or synergies between two seemingly different fields (which can often have immense value-adding effects). Conversely, this same barrier removal has led in the past to reverse effects such as a loss of identity and an inability to deal with complexity.

Owing to the rapid increase in the need to understand complexity (due to its immense beneficial influence on humans and its ability to avert potentially dangerous interactions), a more modern view of knowledge has started to emerge: connectivism. Connectivism conceptualises and visualises knowledge as a mere set of nodes and links [3]. Although simple, this method has attracted much attention for its ability to understand value generation from connections and exchanges. Still, one can only wonder how modern this method or idea really is. Although largely evolved and developed in our modern time (due to technology and the terabytes of available data), a brief historical overview shows countless cases of individuals and collectives observing the effects of interaction and using them to create and grow industry [2]. Optimisations in local 'nodes' will only result in local maxima, and can have the reverse effect, while optimising available networks (of various factors) holds the key to unlocking more knowledge, wealth, value, joy, and prosperity.

It would be unfair to attribute this way of thinking to a specific type of individual, discipline, or collective only. Throughout history, innovators and entrepreneurs (those who are capable of thinking in an interconnected and industrial manner) have appeared from every possible discipline and field. Yet an often overlooked and unknown discipline has these ideas of interconnectedness, value, systems, complexity, and synergy at the heart of its tertiary curriculum and work description [2]. Perhaps what this field has, other than being able merely to see complexity differently or recognise connections, is its ability to engineer and design physical and mental artefacts that are capable of improving human life by extracting value from those connections. Inherent in this desire and need to improve human life is the realisation that the environment and economy are also relevant. And the broad set of skills (legal, financial, and other) and mental connections at the disposal of the individuals in this discipline (which often leads to the criticism that these individuals are jacks of all trades but master of none) allows for more sustainable, humane, value-driven, and environmentallyfriendly solutions $[4,5]$. People are often unaware that such a discipline exists. Yet this discipline is known as industrial engineering.

\subsection{Research problem, purpose, and methodology}

Currently, the formal identity of the industrial engineer remains vague. The word 'industrial' in the title can even be misleading, mainly because it is linked to manufacturing rather than to 'industry' in the broadest sense. Due to the broad knowledge base and application areas made available to industrial engineers, pinning down the commonality has proven difficult. Various works touch on some elements that can help to form an identity (such as IE skills, work preferences, thinking styles, etc.), but they have not been combined. Homo Industrialis, a book discussing the evolution of industry and industrial engineering by Frank Sperotto, provides an excellent review of industrial engineering (or, more broadly, industrial thinking) before it was called 'industrial engineering', and leading to its development as a field [2]. In it a window opens to the true core of the industrial engineer's interests, capabilities, and way of thinking.

To formalise an identity is no easy task, but for the sake of the field it must be done. There is no doubt that IE knowledge is valuable and has proven itself, but employers rarely hire a person with the title 'industrial engineer'; rather, it is 'process engineer', 'supply chain manager', etc. Defining this brand and identity can greatly improve awareness about the field itself, create a resource to which to refer students, and help develop new application areas for industrial thinking and 
modernising industrial engineering methods. In short: the problem this paper aims to address is the lack of a formal industrial engineering identity. The purpose is to develop an industrial engineering identity module.

The scene is set in Section 2 with current knowledge about industrial engineering, in terms of industrial thinking, the inherent skill of 'industrial engineering', the term 'industrial engineering' itself, the nature of industrial engineering work, and modern-day employers of industrial engineers. This is followed by the development of an industrial engineering identity model in Section 3, where three existing identity models are considered, concepts are extracted, and elements to serve as inputs to the industrial engineering identity model are identified. Seven exploratory questions are then formulated and addressed, before the industrial engineering identity tree model is presented in Section 4.

\section{WHAT WE KNOW ABOUT INDUSTRIAL ENGINEERING}

\subsection{Industrial thinking}

A unique thinking style is shared by industrial engineers that is not often articulated. This could be the topic of an article on its own. This goes beyond process thinking (shared with chemical engineering), shares some tools with (but is different from) systems thinking, and contains strands of creativity and entrepreneurial thinking but with a different end goal in mind. That being said, it is absolutely clear that systems, process, creative, and entrepreneurial thinking are vital to the industrial engineer. Yet IE solutions would be lacking without some industrial thinking (the real crux of what makes an industrial engineer unique). Few articles use the term 'industrial thinking' or offer a proper definition of it - although collectively they clarify the idea. Industrial thinking "must begin by differentiating value for the customer from munda - the Japanese term for waste" [6]; it is needed "within research in academia... [due to] the obvious discrepancy between state of the art in robotics research versus actual utilized technology" [7]. "Prefabrication action is a good example of when building industry is utilizing industrial thinking" [8].

Some even go as far as to differentiate between disharmonious industrial thinking and harmonious industrial thinking by arguing that industrial thinking, largely in the second half of the $20^{\text {th }}$ century, focused on profit and growth rather than on harmony (between economy, environment, and society) and often stressed the importance of a single part rather than the synergy of various parts [9]. Unfortunately, the position of the industrial engineer in that era, within the organisational hierarchy, might have forced the Industrial engineer to optimise the immediate environment or company that causes disharmony with the greater environment - much as systems engineering was largely limited, during that timeframe, to develop better weapons for the military. Yet the clarification of roles and the concept of industrial and systems thinking over the decades, and the expansion of the area of consideration, have led to a more aware industrial engineer. Thus the industrial engineer becomes more responsible for taking special care not to repeat the mistakes of the past committed during industrialisation (towards workers, the environment, and even the economy).

For industrial thinking, there are inescapable impulses to consider certain concepts: supply and demand, optimisation, standardisation, end goal, scale, work, value, and human extraction and perception of value. Each of these concepts holds deeper understandings of how the world around us works. For example, supply and demand as an idea is not just about supply chains or commodities; if one filters out the details one can see that virtually everything is a supply-demand relationship, and that there are consequences for not being able to supply or not getting what you demand. This idea can be applied to trees, organisms, and multi-billion Rand organisations alike. An apple tree demands sunlight and supplies fruit; and a failure to meet its demand will affect its supply (it might even affect the long-term growth of the tree). For systems thinking, there are inescapable impulses to consider other concepts: hierarchy, sustainability, flow, interconnectedness, interface, states and system behaviour. Both consider stakeholders - although it could be said that systems thinking applies the definition more broadly. Yet it seems that industrial and systems thinking have a yin yang (an Eastern symbol for symbiotic and balanced affiliation) kind of relationship with one another. If the world is viewed in an interconnected manner, where nodes represent factories, buildings, houses, gardens, and forests, systems thinking would be best-suited to understanding the complexity of it all, but industrial thinking would be best-suited to understanding how humans can 
extract value from it. Systems thinking would be best-suited to differentiating levels of the hierarchy, while industrial thinking can scale activities to different levels of the hierarchy.

In many ways the necessity and benefits of both types of thinking to the industrial engineer can be shown in an article by Ad Sparrius: The Economy is not a Toaster [10]. Although there is no direct mention of industrial thinking, it would be fair to assume that industrial thinking is at work, since most economic activity takes place in industry, and industrial thinking (not to be confused with manufacturing) is best geared to deal with those problems. In Sparrius' paper, the reason that systems thinking requires special care when being applied to larger-scale systems is explored [10]. The paper differentiates between 'hard' and 'soft' systems thinking, while showing the importance of recognising that models do not represent reality [10]. A brief summary of the relevant text is given below [10:

The principle of a hierarchy states that all systems exist in a multi-layer-hierarchy, and the principles valid at one layer are equally valid at all other layers. Nevertheless, extreme care is needed in applying this principle since it contains a hidden danger. A toaster may properly be viewed as a system, although a very simple one. The economy of a country may also be viewed as a system, although a much more complex one.... [Does that mean that] the economy is thus similar to a toaster.... There are fundamental differences between a toaster and the economy.... the toaster has a simple objective but what is the objective of the economy? To grow the domestic product?... or to eliminate poverty? .... or to reduce unemployment? ... at higher levels in a hierarchy, for instance an economy, there are many more stakeholders with many more diverse and inherentlyconflicting values... Hard system thinking, such as system engineering, tackles well defined problems... whereas soft system thinking is more suitable for poorly-defined problems, for instance determining a health care policy in a resource-constrained situation.

\subsection{The inherent skill of 'industrial engineering'}

Why did industrial engineering come to be? And what makes it different? One cannot understand this without first understanding why engineering developed in the first place. The term 'engineering' is commonly thought to stem from the Latin ingenium, meaning (based on several definitions): to do things in a talented, ingenious manner - solution-approached way [11]. This way of life and approach to knowledge is clearly different from that of fields such as law, the humanities, and art (even if there are strong connections between all such fields). However, engineering is often confused with the sciences. The difference is that "while the aim of the scientist is 'to know'; the aim of the engineer is 'to do'. What we do, as 'doers', is apply science to our work" [11]. Early in human development, the distinction might have been unclear because there was no point in creating knowledge for the sake of creating knowledge; the discovery and application of knowledge was often done by one person. This is also due to the limited amount of available knowledge, making it impractical to create specialisations and disciplines. This affected virtually everyone, from doctors (who were seen as people you go to with any disease) to lawyers (who you went to with any kind of legal problem).

The practice of engineering in the broadest sense is perhaps best defined by the Straszacker Commission (in Sperotto [12]):

(a) Involves the use of brains (intellect), energy, materials, systems, money and labour in the conception, operation and maintenance of undertakings for the conservation and optimum utilization of natural resources, for the provision of the means of communication and transportation, as well as the actual production, of a great variety of things.

(b) Bridges the gap between science and human needs, and

(c) Requires the knowledge and skills of several different categories of workers: entrepreneurs, managers, professional engineers, technologists, technicians and manual workers, artisans, operatives and labourers.

However, in modern times, the sheer amount of work that can be done in both the discovery and the application of knowledge has warranted a split between the sciences (often seen as responsible for discovery) and engineering (often seen as responsible for application). Specialisations and disciplines developed as a response to increased available resources, questions available to answer, and the human need to deal with complexity and complicated systems. Naturally, engineering also had to adapt and develop disciplines to deal with the different problems arising from the wide 
spectrum of human endeavours: motion and flow (mechanical), extraction of resources (mining), conversion of chemicals into more valuable chemicals (chemical), and so on.

Interestingly, the advances in these fields, each in its own silo, created a new type of problem that often resulted in uneven advances across the sciences, gaps between theory and practice, and a failure to recognise that the overall value was obtained by designating integration systems that used a balanced combination of engineering and non-engineering knowledge. For example, a car that can travel $10000 \mathrm{~km}$ (mechanical artefact) is less valuable if the longest road (civil infrastructure) is $300 \mathrm{~km}$. Similarly, a phone that has 10 years of battery life (chemical/electronic product) is less useful if the best processor can only perform five calculations an hour (electronic/computer component). More importantly, both of those would have no applied value (as opposed to inherent value) if they were not integrated with human activity, designed to be safe to use, and catered for business and legal considerations. The resolution of such problems is often found in the curriculum of industrial engineers, and is advanced by departments of industrial engineering (academic and industrial).

In the broadest sense, industrial engineering is concerned with a balance between environment, economy, and humanity/society (variations of this formula exist - such as man, money, machine, method, and material - but they rarely capture the true meaning as the three-way relationship identified above does). That is why, more often than not, 'value' in IE does not use units. Rather, it is a unit-less amalgamation of factors. Thus industrial engineering not only exemplifies this definition; it inherently recognises the intricate balance between the factors and the complexity in their interaction. In contrast, other disciplines narrow their focus to specific elements of the definition above (rightfully so in most cases, to further specialised knowledge and increase focus in that field). Interestingly, a brief review of Linkedin shows that industrial engineers will often refer to what they do as 'industrial engineering' [13].

\subsection{The term 'industrial engineer', and the nature of industrial engineering work}

The first formal industrial engineering department was founded at the Pennsylvania State University ini 1909 [13]. In South Africa, the University of Pretoria launched its IE department around 50 years later, in 1962; with Stellenbosch and Wits following shortly after [13]. The North-West University is the most recent to launch an IE department. Yet the term and work nature of industrial engineering was most likely "forged in mills and on shop floors at the turn of the 20th century, [where] industrial engineering sought to tame the social and economic turmoil that emerged as productive activity shifted from fields to cities, from hand tools to dedicated machines and from steam to electrical power" [14]. This is most likely because problems complex and scalable enough to warrant a dedicated engineer resolving them belonged to industry. What industry required at that stage (and still does today) was an individual with the technical skills, capabilities, and problem-solving mindset of an engineer, but with the additional ability to step back and see the whole picture from beginning to end. Additionally, problems in industry most often manifest themselves as problems of scaling up and down, integrating properly, aligning demand with supply, and so on.

Part of the focus of industrial engineering in the 20th century was on work studies, standardisation, and production lines, which required a novel solution to problems resulting from the complex connection between workers and their health (human), productivity (economy) and resources (environment). They also, for example, "experimented with incentive plans, which they believed would enhance motivation and yield workers a fairer wage" [14]. Industrial engineers became "widely known [for] organized and streamlined procurement, inventory, quality and accounting systems. They redesigned machine tools to increase accuracy and efficiency" [14].

It is noteworthy that there is global disagreement about the actual term to describe this type of engineering. In some countries the term 'applied engineer' is preferred (in an attempt to distinguish themselves from industry and factories), and is often defined as the "field concerned with the application of management, design, and technical skills for the design and integration of systems, the execution of new product designs, the improvement of manufacturing processes, and the management and direction of physical and/or technical functions of a firm or organization. Applied Engineering degree programs typically include instruction in basic engineering principles, project management, industrial processes, production and operations management, systems integration and control, quality control, and statistics" [15]. 
Others prefer to promote, use, or merge IE with systems engineer (in an attempt to link the ability to think holistically and use systems thinking in engineering activities). Yet there are minimal differences between the curricula of the different labels. Although those terms might more correctly reflect the nature of this discipline of engineering, the term 'industrial engineering' seems to be the preferred term by far by departments and industry (even though it can sometimes cause a mental link only to industry-related things). Perhaps this is best understood when reviewing where industrial engineering developed, as opposed to systems engineering (which, for a large part of the 20th century, was limited to complex military system development) and applied engineering (a very modern term mainly used in the USA).

\section{$2.421^{\text {st }}$ century employers of industrial engineers}

Various academic departments boast that their scholars are employable in virtually every sector. Yet a deeper look discovers that this commonly-used statement about showing flexibility in job opportunity does not tell the full story. Although it is true that various professions can be employed in various sectors (accountants, administrators, etc.), this does not directly mean that they do different work in different sectors. Accountants will be used as an exhibit in contrast to industrial engineers. Bearing in mind that the work accountants perform is vital and adds value to industry as a whole, it cannot truly be said that the nature of the work varies fundamentally from industry to industry. It revolves more-or-less around certain functions required by companies in general, with specific regulations for carrying out these functions. Some might argue that certain investigative or actuarial branches create diversity; but even then they remain largely confined to certain tools and methods.

On the other hand, industrial engineering as an occupation not only differs from industry to industry, but is also radically changed by different business structures and models. In addition, industrial engineers within the same company but from different departments might use fundamentally different tools and methods. Several studies of the spread of industrial engineers in industry show that their skills, jobs, and specialities vary from very technical engineering-based occupations to softer business- and law-based consulting professions across tens of sectors [5, 13].

\section{DEVELOPING AN INDUSTRIAL ENGINEERING IDENTITY MODEL}

\subsection{Identity models}

Now that a formal introduction to the field has been conducted from various starting points (employers, thinking processes, and the nature of the work), it is time to show how they fit together. The 'iceberg' and several other identity models are often used to conceptualise brands and individual identity [16]. The basic idea is that part of the identity is always visible to the external environment, on which certain assumptions are based about the true identity. Yet the true identity (almost 90 per cent) is submerged, and requires real understanding and analysis for it to be revealed. Examples are shown below:
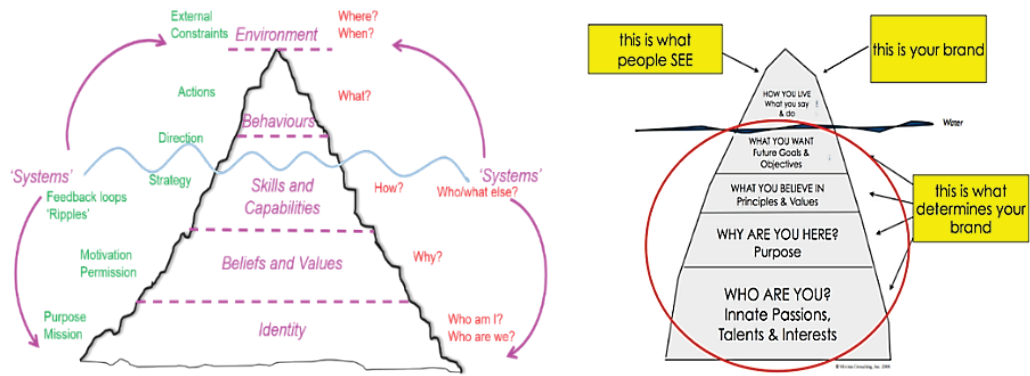

Figure 1: 'Iceberg' brand identity [16] and personal identity [17]

As one goes lower down the iceberg, the real core starts to show (as shown above). Exposed parts of the identity can often be perceived differently, depending on the environment in which they are exposed, or certain external constrains that govern behaviour. Although not traditionally used to express professional identity, these models can be merged with professional identity models to conceptualise and convey a clear message better. 


\subsection{Professional identity}

It is not surprising that, in addition to their personal identity, people prefer to have a clear professional identity. This helps to define roles, strengths, responsibility allocation, and other important work-related aspects. Franziska Trede [18] argues that "every professional has a professional identity; the question is how conscious and purposefully chosen it is. It is impossible to imagine a professional without a professional identity; but it is possible that professionals cannot articulate their professional values and commitments, hence cannot purposefully draw on the core of their identity. Identifying with values and moral principles often remains tacit and nonconscious". He further explains that "it seems that professional identity is closely interwoven with context, and moulded by past experiences and practice traditions" [18].

It is also important to recognise that "considering professional identity - that is, who are we and what do we do - is a natural part of maturation" [19]. It is strange that some sub-disciplines of industrial engineering have moved towards developing this professional identity, while the field itself remains in a bit of a conundrum. For example, the surface level identity of supply chain management (SCM) as defined in an article discussing the professional identity of an SCM professional (in order to avoid the field being taken for granted) "is the value-creation engine of the modern organization" [19].

On the one hand, academics and individuals from industry who possess strong industrial thinking understand the intricacies of the field; yet the lack of formalisation has led other professions to incorrectly evaluate industrial engineering; and this can have tremendously negative effects on the perceived value that the field could add to industry, and can even affect the recruitment of suitable students for the field. "In the undergraduate engineering education context, it should come as no surprise that students may be grappling with future professional roles as part of their autobiographical reasoning processes. They are inundated with ideas and images of what engineers do and what they should value" [20].

The industrial engineering identity faces a special challenge, since it can often be criticised from within engineering departments, based on the perception that it is "distanced from technology, has a less rigorous curriculum and is business engineering" based, which makes it less technical [21]. In addition, some hint at the field's distance from 'real' engineering, due to the large proportion of females in the field [21]. These factors have given rise to the term 'imaginary engineering', since "the perception that industrial engineering is less technical, less hands-on, and less physical contributes to pushing IE to the margins of the engineering hierarchy and establishes boundaries between 'real' engineering disciplines and the 'imaginary' engineering of IE" [21]. But this could not be further from the truth, since students assert that IE is the easiest of the engineering majors, despite having common core curriculum requirements [21]. It would seem, however, that arguing these points does not really solve the problem. If anything, Section 2 should have highlighted how invalid such claims are; and the fact that IE generally has a more equal distribution of the genders should be seen in only the most positive light. Cindy Foor [21] summarises:

Due to industrial engineering's marginalization as a result of the discourse of 'imaginary', we suggest that IE is a discipline where men and women encounter weakened boundaries of gendered norms and archetypes of masculine engineering. Within IE both males and females have faculty role models: The female role models reinforce and even legitimize 'normative' femininity; the male role model confounds constructs of masculinity providing male students with new ways to practice and identify with engineering, which in turn makes IE a more 'inviteful' place for women, too.

The models discussed thus far can help to formalise the IE Identity, further the discussion on the role of the industrial engineer in the knowledge era, and perhaps alleviate these preconceptions and nuances. An additional model - known as the total neuro-logical level model - could assist in finding a way to align the requirements of the individual with the requirements of the profession, and perhaps even improve the teaching of industrial engineering. This model, shown in Figure 2, is centred around the individual's relation to inner and external systems and the difference in the logical level of learning required to reach a higher level. 

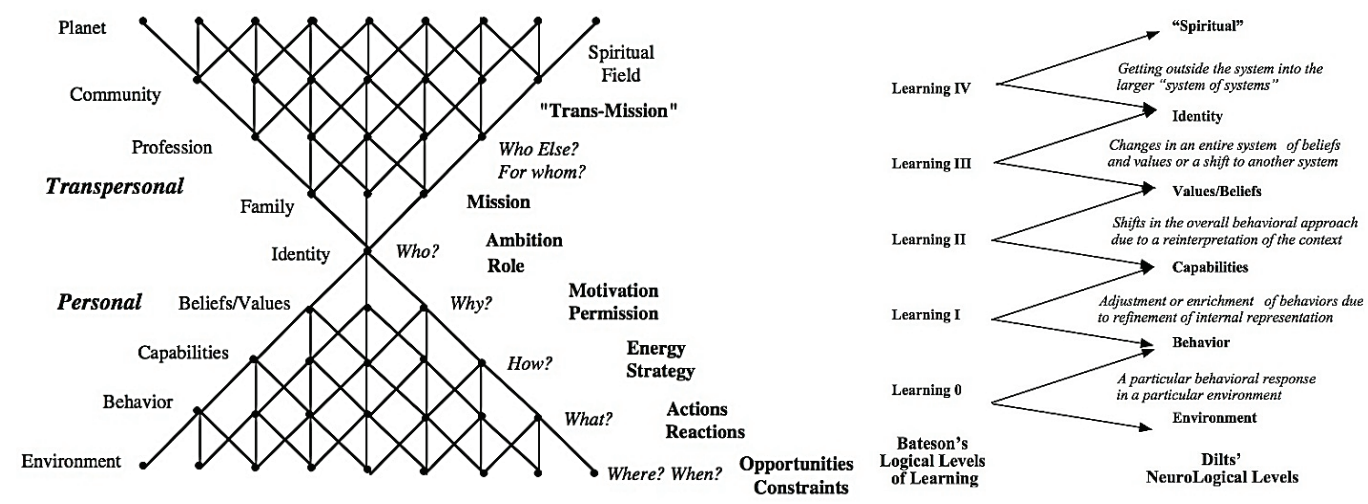

Figure 2: Total system of neuro-logical levels [22]

\subsection{Identity-formalising methodology}

Thus far, the article has merely focused on identifying and discussing the various elements required to formalise the IE identity. This section focuses on the actual methodology used to bring the various pieces of knowledge together into a coherent structure. Although some elements in forming an identity model require a creative licence that is extremely difficult to verbalise, this section will attempt to describe the thought process by answering some necessary and key questions as input to the identity model before proceeding with the design and providing a structure for the identity model. Thus, to formalise the identity model, structural and content inputs are required. In order to form a professional identity, no single identity model is adequate, because the models mentioned above are designed to describe brand, personal, and logical forms of identity. However, they each have elements that could prove useful in formalising a professional identity. Thus the concepts in Table 1 were extracted to be used as inputs to the identity model proposed in 3.4.

\subsubsection{Content input to identity model}

In this section, the extracted questions from each identity model (from Table 1), along with existing questions about identity (extracted from the visual depictions of the identity models in 3.1 and 3.2) were phrased into exploratory questions that could help to pin down some of the finer details of the industrial engineering identity. The answers are largely extracted from the literature review, with some space given for discussion and argument.

\section{Q1: What is the absolute core belief of the industrial engineer without which the field would not exist in the way it does?}

A1: It seems the only defensible answer to this question would be the maximisation of value through balanced means. Whether it is through analytical hierarchy process (AHP), decision analysis, or other tools, the industrial engineer inherently recognises that by failing to consider and include all relevant factors in a decision, the decision will ultimately be flawed, and thus will not result in maximum value because it is not the optimal [2] [9]. The ideal balance would be between economy, environment and, society (the largest macro-systems over which we have some influence or control). Yet, in some cases, it may be acceptable to state it as a balance between the relevant forces at that level.

\section{Q2: How does this core belief manifest itself in thought?}

A2: Industrial engineers think about problems of balance, using several lenses. However, the two that make the industrial engineer unique are industrial and systems thinking [2] [10]. For problems larger than the industrial engineer's sphere of influence, systems thinking is preferred to get a macro view of high-level impact and interaction [10]. Although industrial engineers cannot directly 'influence' those factors, they can design considerations into physical products and conceptual services [14]. 
Table 1: Identity model - extracted inputs

\begin{tabular}{|c|c|c|c|}
\hline $\begin{array}{r}\text { Selected } \\
\text { model }\end{array}$ & Extracted concept & $\begin{array}{l}\text { Extracted elements in } \\
\text { IE-ID model (structure) }\end{array}$ & $\begin{array}{l}\text { Extracted } \\
\text { questions } \\
\text { (content) }\end{array}$ \\
\hline $\begin{array}{l}\text { M1. Brand } \\
\text { identity } \\
\text { (Section } 3.1- \\
\text { Figure } 1 \text { left) }\end{array}$ & $\begin{array}{l}\text { The idea that any identity will naturally } \\
\text { have a visible element (based on which } \\
\text { society can form a perception), and a } \\
\text { true hidden identity is absolutely vital in } \\
\text { a professional identity, due to a clear } \\
\text { discrepancy between what industrial } \\
\text { engineers actually do and what people } \\
\text { think they do, enjoy, and are capable of } \\
\text { doing. }\end{array}$ & $\begin{array}{l}\text { M1.1. Societal } \\
\text { perception - "What } \\
\text { people see" [16] } \\
\text { M1.2. Passion and } \\
\text { interests - "innate } \\
\text { passion talents, } \\
\text { interests" [16] }\end{array}$ & $\begin{array}{l}\text { 1) What are your } \\
\text { passions, skills and } \\
\text { capability? } \\
\text { 2) How are you } \\
\text { perceived? }\end{array}$ \\
\hline $\begin{array}{l}\text { M2. Personal } \\
\text { identity } \\
\text { (Section } 3.1- \\
\text { Figure } 1 \text { right) }\end{array}$ & $\begin{array}{l}\text { This model is used as the basis for the } \\
\text { identity, since there is a correlation } \\
\text { between personal and professional } \\
\text { identity. The different levels are } \\
\text { extracted, but can be compressed in the } \\
\text { professional identity model. Important } \\
\text { questions are extracted from different } \\
\text { levels that can shed light on important } \\
\text { elements of the IE professional identity. }\end{array}$ & $\begin{array}{l}\text { M2.1. Environment } \\
\text { M2.2. Behaviour } \\
\text { M2.3 Skills and } \\
\text { capabilities } \\
\text { M2.4 Beliefs and } \\
\text { values } \\
\text { M2.5 Identity }\end{array}$ & $\begin{array}{l}\text { 1) How do you } \\
\text { react to external } \\
\text { constraints? [17] } \\
\text { 2) What is your } \\
\text { purpose and } \\
\text { mission? [17] } \\
\text { 3) What are your } \\
\text { motivators? }\end{array}$ \\
\hline $\begin{array}{l}\text { M3. Neuro- } \\
\text { logical level } \\
\text { identity } \\
\text { (Section } 3.2- \\
\text { Figure 2) }\end{array}$ & $\begin{array}{l}\text { This model, unlike } M 1 \text { and } M 2 \text {, focuses } \\
\text { more on the neuro-logical structure of } \\
\text { learning and thinking (which is vital in } \\
\text { this case, due to the uniqueness of } \\
\text { industrial thinking). Additionally, it } \\
\text { seems to suggest that transpersonal } \\
\text { levels (spiritual, community, etc.) funnel } \\
\text { into an ambition and role that affects } \\
\text { the lower level (opportunities and } \\
\text { constraints) in response to the external } \\
\text { environment. It also separates the trans- } \\
\text { mission from the mission that is usable in } \\
\text { this instance, since there might be two } \\
\text { different levels for core vs fundamental } \\
\text { worldviews. }\end{array}$ & $\begin{array}{l}\text { M3.1. Environment } \\
\text { M3.2. Ambition/role } \\
\text { [17] } \\
\text { M3.3 Learning style } \\
\text { "Learning levels 0-IV" } \\
\text { [17] } \\
\text { M3.4 Core belief } \\
\text { "Mission" [17] } \\
\text { M3.5 Fundamental } \\
\text { belief } \\
\text { "Trans-mission" [17] }\end{array}$ & $\begin{array}{l}\text { 1) How do you } \\
\text { think about the } \\
\text { world and its } \\
\text { problems? } \\
\text { 2) What do you } \\
\text { see as your role? } \\
\text { 3) What are your } \\
\text { spiritual } \\
\text { (worldview) } \\
\text { beliefs? } \\
\text { 4) What are your } \\
\text { core beliefs? }\end{array}$ \\
\hline
\end{tabular}

Q3: What level higher than this belief is out of the control of the industrial engineer [the way the world works]? What implications does it have for the field?

A3: More broadly, the industrial engineer can be said to believe that the world strives for balance in its broadest sense, which is a desirable intermediary state between opposing forces [2]. The implications of answering this question is the definition of a boundary space where industrial thinking and systems thinking swap. In theory, this boundary area is continuously changing, and is largely affected by human ambition, technology development, and relevant factors such as stability, scalability, and sustainability [2]. Perhaps further defining this can clarify the role difference of the industrial engineer as opposed to a systems engineer.

\section{Q4: What are some of the values and motivations of industrial engineers?}

A4: Industrial engineers, like engineers in general, should hold true to applying scientific knowledge for human benefit. The consideration of human benefit should be global, as opposed to localised efficiencies (which would make the optimisation of killing in war an acceptable practice) [2] [8] [9]. Industrial engineers value efficiency, human wellbeing, environmental sustainability, the application of knowledge, and the value of fairness (wages, work, and opportunity).

\section{Q5: What types of skills and capabilities do industrial engineers possess?}

A5: Due to the complex nature of IE work and the sea of considerations from the macroenvironments, the industrial engineer's greatest capability is interconnectedness with all major nodes of other fields of study [5] [12] [13]. This presents a challenge in itself, since it requires industrial engineers to be aware naturally of where the solution to any problem might lie, even if they do not possess the solution themselves. Yet it allows the Industrial engineer to develop 
networks with fellow industrial engineers with differing interests to create a type of knowledgesharing 'mesh network' [12]. Other skills and capabilities unique to industrial engineers are: modelling (business process, simulation, statistical, and other), conceptual design, rapid prototyping, needs analysis, systems design, interface design, facility and supply chain design, design of experiments, business analytics, strategy development, quality management, operation management, project management, requirements analysis, root cause analysis, change management, process mapping, and optimisation [13].

\section{Q6: How are these skills and capabilities affected by the external environment 'behaviour'?}

A6: These skills and capabilities might be used simultaneously, sequentially, partially, or consequentially. They might be adjusted for different environments, teams, or situations. Yet the common behaviour displayed in all these situations by the industrial engineer is a persistence in finding the relevant tools, knowledge, and individuals to resolve a problem. If the industrial engineer is not qualified to use the specific tool/knowledge field, their role changes to a quality manager/integrator [2] [6] [14]. This handing-off is key to the success of industrial engineering work, since it inherently recognises the capability of other disciplines and respects them. In this way tasks are done more efficiently and the network of the industrial engineer is expanded.

\section{Q7: What environments can they be applied to?}

A7: Virtually any environment that can be classified as an Industry requires full-time industrial engineers due to the sheer number of value/balance-driven problems that arise from internal activities and external forces affecting the work environment [5] [13] [21]. For more decentralised businesses that are still part of an Industry but cannot financially justify the employment of a fulltime industrial engineer, customisable artefact-based templates (with built-in industrial thinking/IE tools) that standardise or simplify certain high level concerns to an appropriate level for that business are often designed or built by industrial engineers. This has often strengthened the perception that industrial engineers are 'jack of all trades and masters of none'. However, the traditional perception that industrial engineers are 'jack of all trades' and should be 'connected to all fields of knowledge and master of none' is, more realistically, that they are 'master of some'. Collectively, however, industrial engineers span the network of knowledge, and can expand their networks and knowledge by integrating with their peers.

\subsubsection{Structural input to identity model}

This section focuses on forming the content into a coherent structure of different identity levels. Various potential levels were described and extracted from the identity models described in Table 1 ; but they created unnecessary repetition. Thus the identity levels were compressed into eight levels with a similar structure to that in Figure 2 . The defined levels and the relevant instigator for the need for that level (extracted from the third column of Table 1) are listed below:

Level 1 (M1.1) - Societal perception lens: The social perception of IE should be that it is the field connected with all fields of knowledge and masters of some.

Level 2 (Merge M2.1, M2.2, and M3.1) - External behaviour: Industrial engineers are adaptive and proactive in responding to external environment stimulation and forces, much as the leaves of a tree react to different weather conditions. Yet the common behaviour displayed in all these situations by the industrial engineer is a persistence in finding the relevant tools, knowledge and individuals to resolve a problem.

Level 3 (Merge M2.3) - Skills and capabilities: Industrial engineers define, design, deploy, and refine conceptual and physical solutions aimed at generating value for Industry. Industrial engineering skills and capabilities might be used simultaneously, sequentially, partially, or consequentially. If the industrial engineer is not qualified to use the specific tool or knowledge field, their role changes to a quality manager or integrator among specialists who are better suited to deal with the subject matter. This handing-off is key to the success of industrial engineering work, since it inherently recognises the capability of other disciplines and respects them.

Level 4 (Rephrase M3.2 and M2.3) - Knowledge fields/disciplines: The fields in which industrial engineers can prosper usually include elements of design and management such as: project management, information systems, systems engineering, modelling and simulation, mechatronics 
and automation, robotics and artificial intelligence, operations research and operations management, facilities management and maintenance systems, quality management systems, and logistics and supply chain management. That list is not exhaustive.

Level 5 (Merge M1.2, M2.4) - Value and motivator: Application for human benefit is the greatest value and motivator of industrial engineers. Other values include efficiency, human wellbeing, fairness, sustainability, and the application of theory and knowledge.

Level 6 (Merge M3.3, M2.2, and M2.5) - Thinking style: Industrial and systems thinking. These two thinking modes must be present to connect knowledge with the core belief in an Industrial's mind, just as a tree is simultaneously exposed to the environment above and below ground.

Level 7 (M3.4) - Core belief: The crux of what makes industrial engineering different and valuable as a discipline is maximising the extraction of value through balanced means.

Level 8 (M3.5) - Fundamental belief: Balance is intrinsically valuable, and can be one of the most prominent beliefs.

\section{$4 \quad$ INDUSTRIAL ENGINEERING IDENTITY TREE MODEL}

The information from 3.3 provides the necessary structural and content inputs for a professional identity model to be developed. However, for the visual representation of the industrial engineering Identity, a different analogy from that of the iceberg is used. The selected analogy is a tree: rather like the iceberg, a significant part of it is unseen, under the surface; but, unlike the iceberg, it better represents the idea of resources, value extraction, and balance with the ecosystem. The Pando tree (a variety of aspen) is often defined as the single largest organism because a massive underground root system connects each apparently individual tree [23]. Grant [23] explains that "a group of thousands of aspens can actually be a single organism, sharing a root system and a unique set of genes". Thus the trees share resources, react in a common way to environmental factors, and share a similar genetic makeup [23]. In addition, the trees expand by sending out roots to grow (much as industrial engineers encourage close members to join the field) [23]. Notably, environmental forces can sometimes create a separation between different 'organisms', yet they still maintain large networks.
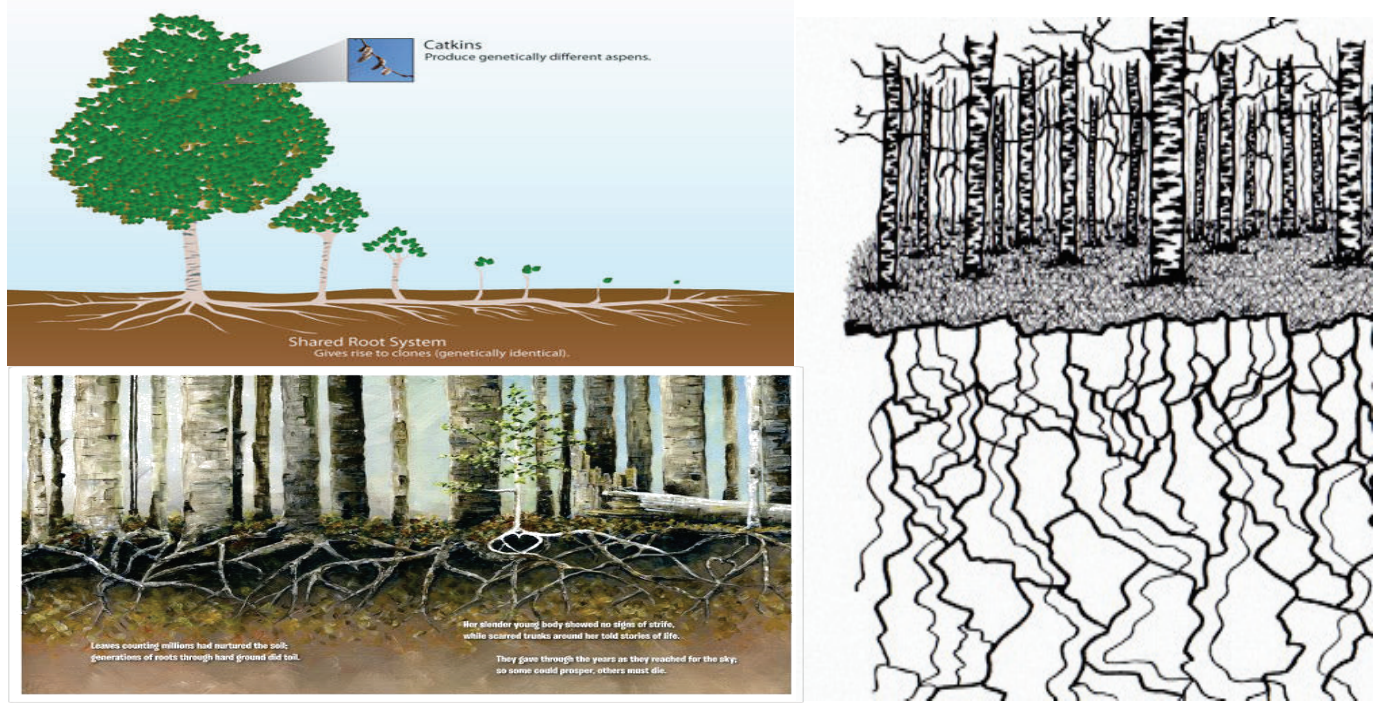

Figure 3: Visual depiction of Pando (aspen) tree interconnected root system [24-26]. 


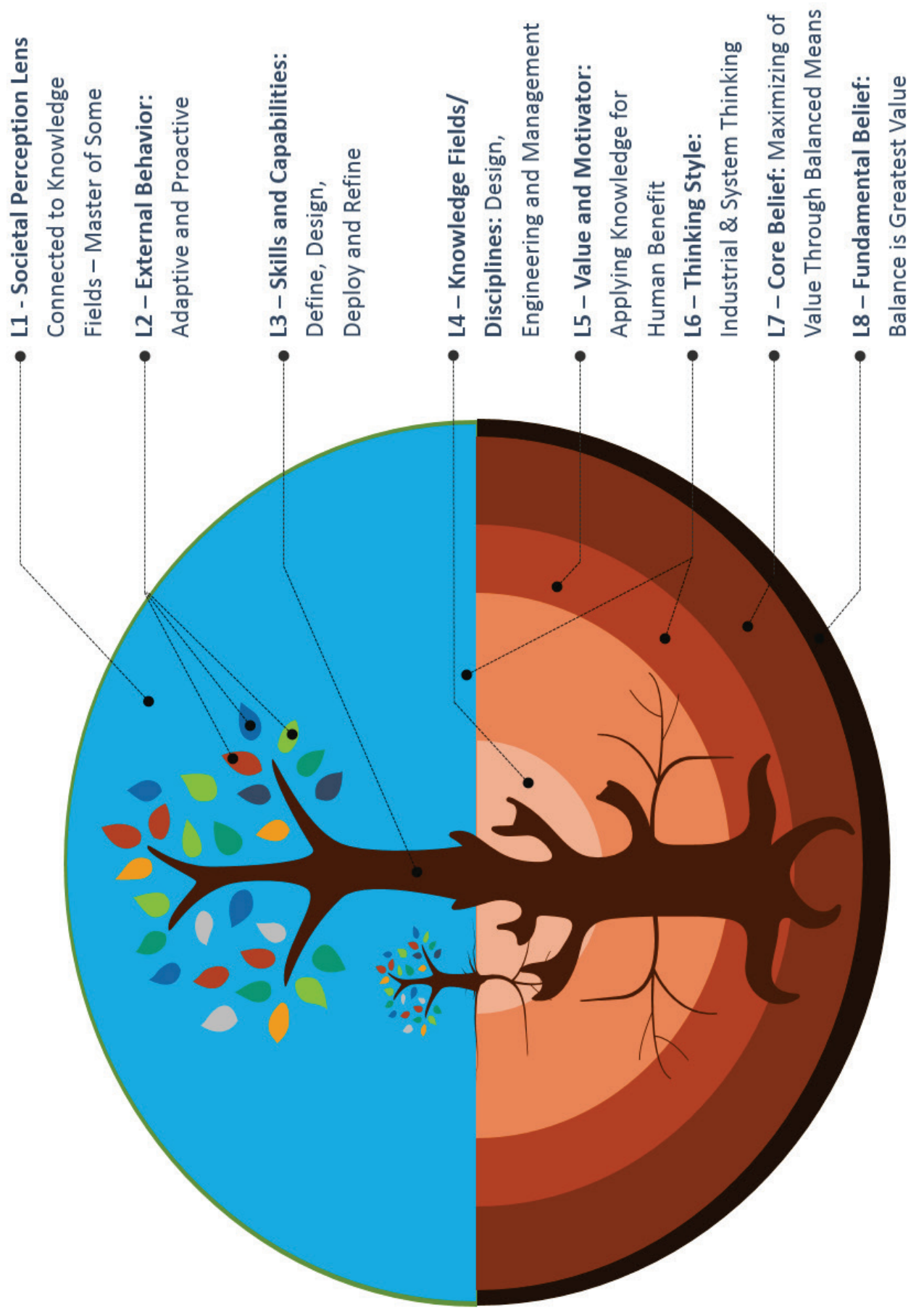

Figure 4: Industrial engineering identity model (IE-ID) [own work]

The industrial engineering identity (IE-ID) is represented visually in Figure 4.

\section{CONCLUSIONS AND FUTURE RESEARCH}

This article was not an attempt to re-define industrial engineering; rather, it was an attempt to formalise the identity in the hope of realigning it with the values that have made it a successful 
discipline. Although the article is largely targeted at professionals who seek an improved formal identity, the academic world could benefit from revisiting how it educates industrial engineers. "The role of higher education is contested and includes educating students for global citizenship to producing work-ready graduates. The former tends to foreground the notion of values, ethics and developing professional identities whereas the latter focuses on work training and employability" [18]. This is worth special consideration if one bears in mind the generation differences about what is considered valuable, or the degree of loyalty that people have to certain parts of their life (including their profession) [27]. Sociologists classify the current entrants into university as part of 'Generation Z' (the first generation to spend their entire life exposed to the internet) [28]; and their beliefs, identity, values, and aspirations are radically different from those of the lecturers who teach them. The issues arising from such generational differences are better left for another article; however, it is important to note the great impact they could have.

The Engineering Council of South Africa (ECSA) and other entities involved in defining the work of various disciplines should also play a more proactive role in promoting and protecting engineering work. At the moment, industrial engineering work remains virtually unprotected. If professional registration is truly to mean something, it should be that the designs that result from industrial engineering work are of a certain quality and display the capability of the industrial engineer performing them. Formalising an identity is only part of this process. Much research needs to be done that will further define the nature of industrial engineering work. Future research aims to show how the undergraduate curriculum should be revisited in order to place a greater emphasis on incorporating the industry identity and to develop certain capabilities that are suited to the knowledge era:

1. A focus on the ability to prototype and scale ideas rapidly.

2. An ability to know intuitively in what field of knowledge a solution lies. (The point here is that, even if industrial engineers cannot solve a problem, they know who can, and they know how to measure and manage them.)

3. A greater focus on understanding complexity and on simplifying concepts to be communicated better.

4. Greater research ability that helps to develop knowledge rapidly, which can then be consolidated through a proactive learn-apply-adjust-repeat cycle.

5. An inherent ability to create, grow, strengthen, and sustain one's network.

6. The appreciation that time saved through technology and programmes is time that should be spent thinking on other aspects of the system.

Lastly, research can be done into why high school students who choose industrial engineering should be developed, and how to ensure a more equal distribution of race. It is pleasing to see the number of industrial engineers who lead global projects. Still, more projects or initiatives are shifting into rural regions in an attempt to serve low-income and rural communities (who make up 80 per cent of the world's population). In South Africa, more and more students from disadvantaged communities should be shown the potential that industrial engineering (as a field of study) could have for their communities, and how this body of knowledge could help them to give back to their communities.

\section{REFERENCES}

[1] GoodReads. Nadeem Aslam. Available from: http://www.goodreads.com/quotes/402814-pull-a-threadhere-and-you-ll-find-it-s-attached-to [Accessed 1 November 2015].

[2] Sperotto, F. 1994. In the footsteps of homo industrialis. Johannesburg: Picsie Books.

[3] AlDahdouh, A.A., Osório, A.J. and Caires, S. 2015. Understanding knowledge network, learning and connectivism. International Journal of Instructional Technology and Distance Learning, 12(10), pp. 3-21.

[4] SUN. 2016. Prospective undergraduates. Industrial Engineering, Stellenbosch University. Available from: http://ie.sun.ac.za/prospective-undergraduates/ [Accessed 1 May 2016].

[5] Schutte, C., Kennon, D. \& Bam, W. 2016. The status and challenges of industrial engineering in South Africa. The South African Journal of Industrial Engineering, 27(1), pp. 1-19.

[6] Womack, J.P. and Jones, D.T. 1996. Beyond Toyota: How to root out waste and pursue perfection. Harvard Business Review, 74(5), pp. 140.

[7] Pires, J.N., Nilsson, K. and Petersen, H.G. 2005. From the guest editors: Industrial robotics applications and industry-academia cooperation in Europe. Robotics \& Automation Magazine, IEEE, 12(3), pp. 5-6.

[8] Jansson, C. and Tägtsten, S. 2007. Product development in the building industry based on industrial thinking method for connection design. Master's Thesis, Chalmers University of Technology, Goteborg, Sweden. 
[9] Semashko, L. 2013. The ABC of harmony for world peace, harmonious civilization and Tetranet thinking: Global Textbook, Lulu.com.

[10] Sparrius, A. 2008. The economy is not a toaster. INCOSE SA. Available from: http://earf.meraka.org.za/earfhome/library/systems-thinking/Toaster.pdf [Accessed 15 April 2015].

[11] Wier, J. 2001. From ingenium to engineer. Available from: http://www.wierassociates.com/History\%20Articles/HA06.htm [Accessed 1 November 2015].

[12] Sperotto, F. 2015. The development of the industrial engineering profession in South Africa. The South African Journal of Industrial Engineering, 26(2), pp.1-9.

[13] Van Dyk, L. 2014. A census of South African industrial engineers, based on data extracted from Linkedin. Southern African Institute for Industrial Engineering Conference.

[14] Bailey, D.E. and Barley, S.R. 2005. Return to work: Toward post-industrial engineering. IIE Transactions, 37(8), pp .737-752.

[15] GoEngineering. Applied engineering. Available from: http://www.goengineer.com/glossary/appliedengineering/ [Accessed 1 May 2016].

[16] Villalobos, M. 2016. The identity iceberg. Available from: http://www.michellevillalobos.com/audio_video/cool-inspiring-images-slide/the-identity-iceberg.html [Accessed 1 May 2016].

[17] Vievolve. 2016. Logical levels of thinking \& change. Available from: http://vievolvelearninganddevelopment.vievolve.com/logical-levels-of-thinking-and-change/ [Accessed 1 May 2016].

[18] Trede, F. 2012. Role of work-integrated learning in developing professionalism and professional identity. Asia-Pacific Journal of Cooperative Education, 13(3), pp. 159-167.

[19] Fawcett, S.E. and Waller, M.A. 2013. Considering supply chain management's professional identity: The beautiful discipline (or, "We don't cure cancer, but we do make a big difference”). Journal of Business Logistics, 34(3), pp. 183-188.

[20] Eliot, M. and Turns, J. 2011. Constructing professional portfolios: Sense-making and professional identity development for engineering undergraduates. Journal of Engineering Education, 100(4), p. 630.

[21] Foor, C.E. and Walden, S.E. 2009. 'Imaginary Engineering' or 'Re-imagined Engineering': Negotiating gendered identities in the borderland of a college of engineering. NWSA Journal, 21(2), p.41-64.

[22] Dilts, R.B. 2014. A brief history of logical levels. Available from: http://www.nlpu.com/Articles/LevelsSummary.htm [Accessed 1 May 2016].

[23] Grant, M.C. 1993. The trembling giant. Available from: http: / /discovermagazine.com/1993/oct/thetremblinggian285 [Accessed 1 May 2016].

[24] Pinterest. 2016. Aspen roots visual. Available from: https://s-media-cacheak0.pinimg.com/736x/80/4d/b1/804db12bd98bcae01bac9f7218e03614.jpg [Accessed 1 May 2016].

[25] Workofhishands.com. 2016. Aspen root. Available from: http://www.workofhishands.com/wpcontent/uploads/2016/03/roots.jpg [Accessed 1 May 2016].

[26] UnusualSuspect. 2016. Tree roots. Available from: https://www.threadless.com/designs/tree-roots [Accessed 1 May 2016].

[27] Glass, A. 2007. Understanding generational differences for competitive success. Industrial and Commercial Training, 39(2), pp. 98-103.

[28] McCrindle, M. and Wolfinger, E. 2010. Generations defined. Ethos, 18(1), p. 8. 